Meta

Journal des traducteurs

Translators' Journal

\title{
Syntax, Readability and Ideology in Children's Literature
}

\section{Tiina Puurtinen}

Volume 43, numéro 4, décembre 1998

L'approche basée sur le corpus

The Corpus-based Approach

URI : https://id.erudit.org/iderudit/003879ar

DOI : https://doi.org/10.7202/003879ar

Aller au sommaire du numéro

Éditeur(s)

Les Presses de l'Université de Montréal

ISSN

0026-0452 (imprimé)

1492-1421 (numérique)

Découvrir la revue

Citer cet article

Puurtinen, T. (1998). Syntax, Readability and Ideology in Children's Literature. Meta, 43(4), 524-533. https://doi.org/10.7202/003879ar

\section{Résumé de l'article}

Cet article décrit les buts et la méthodologie d'une nouvelle recherche dans le domaine de la littérature pour enfants. L'étude se fait à partir d'un corpus composite - textes originaux en anglais et en finnois ainsi que des textes finois traduits vers l'anglais. L'auteur se penche d'abord sur les constructions non finies en tant que mesure de la lisibilité des livres pour enfants; mais le but de l'article est d'inférer, par l'interprétation de modèles lexico-grammaticaux observés dans le corpus, les normes idéologiques qui prévalent dans la littérature anglaise et finnoise pour enfants. 


\title{
SYNTAX, READABILITY AND IDEOLOGY IN CHILDREN'S LITERATURE
}

\author{
TIINA PUURTINEN \\ University of Joensuu, Joensuu, Finland
}

\begin{abstract}
Résumé
Cet article décrit les buts et la méthodologie d'une nouvelle recherche dans le domaine de la littérature pour enfants. L'étude se fait à partir d'un corpus composite - textes originaux en anglais et en finnois ainsi que des textes finois traduits vers l'anglais. L'auteur se penche d'abord sur les constructions non finies en tant que mesure de la lisibilité des livres pour enfants; mais le but de l'article est d'inférer, par l'interprétation de modèles lexico-grammaticaux observés dans le corpus, les normes idéologiques qui prévalent dans la littérature anglaise et finnoise pour enfants.
\end{abstract}

\begin{abstract}
This article outlines the aims and methodology of a new study in the field of children's literature. The research makes use of a composite corpus representing original English, original Finnish and translated Finnish from English. The initial focus of this investigation is the analysis of nonfinite constructions, taken as a measure of readability of children's books. Ultimately its aim is to infer, through the interpretation of the lexico-grammatical patterns emerging in the corpus, the ideological norms prevailing in the literary systems of English and Finnish children's fiction.
\end{abstract}

\section{INTRODUCTION}

Several translation scholars (Baker 1995, 1996, this volume; Toury 1980, 1995) have suggested that translated texts tend to deviate from original target language texts in various ways, i.e. it is possible to identify features which are either exclusive to translation or occur with a higher or lower frequency in translations than in originals. On the one hand, systematic, large-scale, corpus-based research into features common to all translations could lead to the identification of universals of translation. On the other hand, research on a smaller scale, restricted to translations of a specified text type in a given socio-cultural context, and maybe even from a particular source language, can yield information about translational norms, which have been declared one of the most important objects of investigation within the field (Chesterman 1993; Delabastita 1991; Hermans 1991; Toury 1995).

This paper outlines such research based on a combination of a parallel and a comparable corpus of children's books: English source texts, their Finnish translations and Finnish originals. ${ }^{1}$ The research will be twofold: First, it compares the frequency of nonfinite syntactic constructions (NCs), relevant to readability, in Finnish children's books and in English-Finnish translations; English source texts serve as one source of explanations for translational solutions. The assumed higher degree of nonfiniteness in the translations may be seen as a feature of translationese and as an indication of a difference between the syntactic norms of these two literary subsystems. It is also likely to have an effect on the readability of the translations, which in turn may have consequences for the readership. The second line of research investigates particular micro-

Meta, XLIII, 4, 1998 
and macro-linguistic strategies which reflect ideology, i.e. implicit assumptions, beliefs and power relations in English and Finnish children's books. Apart from an attempt to uncover implicit ideology, the study aims to compare different linguistic realisations of ideology in English and Finnish texts, and to reveal the potential manipulation of ideological elements in translation. These two research interests are not completely disconnected, as I will try to show in this paper. Before a more detailed account of the aims and hypotheses, however, I would like to demonstrate the importance of studying (translated) children's literature and especially those linguistic and ideological elements in focus here.

\section{ROLE OF CHILDREN'S LITERATURE}

Children's literature is generally seen as a peripheral and uninteresting object of study despite the manifold role it plays as an educational, social and ideological instrument. Apart from being entertainment and a tool for developing children's reading skills, it is also an important conveyor of world knowledge, ideas, values, and accepted behaviour. Didacticism is always more or less discernible, explicitly or implicitly, in children's books. This principle of didacticism, of "usefulness" to the child, is complemented or sometimes counteracted by the requirement of comprehensibility: both the language and the content of children's books are adjusted to readers' comprehension and reading abilities. When children's books are translated, it may be necessary to make various adjustments in order to adhere to the notions of what is good and appropriate for children, as well as what is considered the suitable level of difficulty in a given target culture.

Readability, or ease of reading and understanding determined by linguistic difficulty, is one aspect of comprehensibility. ${ }^{2}$ Presently the concept is also understood to cover speakability (the term from Snell-Hornby 1988: 35), i.e. the suitability of a text to be read aloud fluently, which is one of the most important qualities of children's books as children's books are read aloud not only by adults but also by children themselves. Sentence length and sentence complexity are among the determinants of readability that have attracted much research and controversy; of these two factors, sentence complexity seems to affect readability more than length in Finnish texts read by children (see e.g. Puranen 1981). Therefore a translator's attempt to avoid long sentences by using contracted clauses and other concise syntactic structures (more about these in the next section) may result in an overtly difficult Finnish text. Similarly, an effort to transfer English nominalisations which may be a particular author's stylistic feature to the target text may contrast with the norms of Finnish children's literature or the expectations of Finnish readers. To put it in theoretical or, more specifically, in Tourian terms (Toury 1995), the acceptability of such a translation would probably be lower owing to its nonconformity to the linguistic norms of the target literary (sub)system. The consequences for the child readers may be negative: whereas books which are pleasant and interesting to read encourage children to read more and may create a lifelong interest in literature, difficult, incomprehensible books are likely to alienate them from reading and may thus even slow down the development of reading skills.

The ideological content in a story is sometimes made explicit through clear statements of moral or ethical principles, but most often it remains implicit and thus perhaps more effective and more difficult to challenge. In critical linguistics, ideology is defined as the taken-for-granted assumptions, beliefs and value systems shared collectively by social groups (Simpson 1993: 5). It has also been defined as meaning in the service of power, as the use of language to establish and sustain relationships of domi- 
nation (Thompson 1990: 56, quoted in Knowles \& Malmkjær 1996: 43). As Knowles and Malmkjær (1996: 43-44) point out, the adult-child relationship is a relationship of power. Critical linguistics explores the ways in which ideologies are coded in linguistic expression. Language, such as the lexical and syntactic choices made by a writer to describe events, characters and their relationships, can help create and maintain beliefs, values and relations of power. Syntactic structures can reflect a world-view; nominalisation, passivisation and theme-rheme structure create a particular perspective on the events and processes portrayed, which need not be the conscious intention of the writer (see the examples in section 4).

Seen in this light, the language of children's literary and non-literary texts is a very powerful socialising instrument, as Halliday (1978) emphasizes: through language a child learns about customs, hierarchies and attitudes; therefore the language of literature can promote and reinforce the adoption of these customs, etc. Stephens (1992: 89) maintains that every book has an implicit ideology, usually in the form of beliefs and values taken for granted in society. This taken-for-grantedness makes it difficult to reveal the underlying assumptions, because the analyst often entertains similar assumptions and values of which he is unaware.

Despite its importance as an ideological instrument, children's literature has mostly been neglected in critical linguistic research. Stephens (1992) analyses narrative techniques and intertextuality from the ideological point of view, but does not take a linguistic approach to ideology. Knowles and Malmkjær (1996), on the other hand, carry out a linguistic analysis of ideology in children's books. The translation of children's literature has attracted even less scholarly attention. In Finland, translations account for $65-70 \%$ of the literature published annually for children; about half of all translations are from English. Almost every Finnish child is exposed to translated literature. These translations are bound to have a significant effect on the way children experience literature, and the language of translated texts may have some bearing on their language development and acceptance of ideas.

\section{SYNTAX AND READABILITY}

Complex sentence structures such as Finnish nonfinite constructions (NCs) are likely to have a negative impact on the readability and speakability of a text. This has been demonstrated in empirical tests with children as test subjects (Puurtinen 1994, 1995). The cognitive difficulty of NCs can be explained by a number of factors. First, they can hold a lot of information in a very compact form, and they tend to increase the information density or lexical density (see Halliday 1986: 330-331, 1989: 61-62) of the text ${ }^{3}$ they seem to contain less grammatical redundancy than finite constructions. In other words, they can contain a great number of tightly packed propositions, whose relations are not always made explicit because of a lack of conjunctions. Compare the two translations of the same source text sentence (from The Wizard of $O z$ by L. Frank Baum, 1982/1900) in example 1 below (NCs are in bold face, finite verbs italicized).

Example 1

Many crows and other birds flew into the cornfield, but as soon as they saw me they flew away again, thinking I was a Munchkin; and this pleased me and made me feel that I was quite an important person. (Baum 1982: n. pag.)

Maissipellolle lensi monta varista ja muita lintuja, mutta heti minut nähtyään ne lensivät jälleen pois luullen minua Rouskijaksi; ja se miellytti minua ja sai minut tuntemaan itseni melkoisen tärkeäksi henkilöksi. (Helanen-Ahtola 1977: 33) 
(word-for-word translation: Into the cornfield flew many crows and other birds, but immediately after seeing me they flew away again taking me for a Munchkin; and it pleased me and made me feel quite an important person.)

Monia variksia ja muita lintuja lensi maissipellolle, mutta heti kun ne näkivät minut, ne lensivät tiehensä sillä ne luulivat minua maiskiseksi, ja siitä minä ilahduin sillä se sai minut tuntemaan itseni tärkeäksi henkilöksi. (Juva 1977: 31)

(word-for-word translation: Many crows and other birds flew into the cornfield, but as soon as they saw me, they flew away because they took me for a Munchkin, and because of this I became happy because it made me feel an important person.)

The first translation has two NCs, which do not include explicit signals of clausal relations. The second translation uses the conjunction kun ('when', 'as soon as') to signal a time relation (as soon as they saw me), sillä ('because') to indicate a cause-effect relation (because they thought I was a Munchkin), and a "superfluous" sillä-conjunction indicating another cause-effect relation (it pleased me because it made me feel...) of which there is no signal in the source text.

Moreover, NCs with premodifiers are left-branching structures, which are likely to burden the reader's working memory more than finite, right-branching structures. In left-branching structures the predictability of the lexical items is also lower (see example 2, which shows the Finnish translation of a sentence in C.S. Lewis's The Last Battle 1980/1956).

\section{Example 2}

No one who had ever seen a real lion would have been taken in for a moment. (Lewis 1980: 15)

Ei kukaan kerrankin oikean leijonan nähnyt elollinen olisi hetkeäkään uskonut tähän petkutukseen. (Helakisa 1988: 11)

(word-for-word transl.: No - once a real lion seen - living creature would for a moment have believed in this cheating.)

The translation includes a rather heavy premodified participial attribute construction (in bold face), which is a clearly left-branching structure, the head word being the last item in the construction. An alternative right-branching structure with the head word coming first, followed by a relative clause (in bold face), might read as follows:

Ei kukaan elollinen, joka on kerrankin nähnyt oikean leijonan, olisi hetkeäkään uskonut tähän petkutukseen. (my translation)

(word-for-word transl.: No living creature, who has once seen a real lion, would for a moment have believed in this cheating.)

Finally, some NCs can be considered grammatical metaphors, which are marked, incongruent forms of encoding. An action is denoted by a noun or a participial attribute instead of by a verb, which is regarded as the unmarked form in English (see Halliday 1986 and Ravelli 1988 for an elaboration of the concept, and Karvonen 1991 and Puurtinen 1993, 1995: 96-103 for its application to Finnish texts). Similarly, qualities which are usually realised by adjectives can be expressed with nouns, and clausal relations, normally realised by conjunctions, can be expressed by nonfinite verb forms. Example 3 shows a metaphorical (nominalising) and congruent (finite) translation of the same sentence in The Wizard of $\mathrm{Oz}$.

\section{Example 3}

What worried her most was that the bread was nearly gone, and another meal for herself and Toto would empty the basket. (Baum 1982: n. pag.) 
Eniten häntä huolestutti se, että leipä oli miltei syöty, ja yksi Toton ja hänen itsensä nauttima ateria tekisi siitä lopun. (Helanen-Ahtola 1977: 42)

(word-for-word transl.: Most she was worried by (the fact) that the bread was nearly eaten, and one - by Toto and herself eaten - meal would make an end of it.)

Eniten Dorothya huoletti se että leipä oli loppumassa, hänen ja Toton ei tarvitsisi syödä kuin kerran niin kori olisi tyhjä. (Juva 1977: 41)

(word-for-word transl.: Most Dorothy was worried by (the fact) that the bread was running out, she and Toto would not need to eat more than once so the basket would be empty.)

In Helanen-Ahtola's translation the process of eating is realised as a noun (ateria, 'meal') and is made the theme and the grammatical subject of the clause (as in the source text). Juva's congruent version is more directly related to the concrete event: those who act are realised as actors, the action is denoted by a verb, and the result of the action (an empty basket) is signalled by the conjunction niin ('so').

The congruency of various lexicogrammatical representations is naturally a language-specific issue, but Halliday's and Ravelli's views seem to be applicable to Finnish as well. A process or action which is expressed by a Finnish nominalisation is condensed into a state or a thing, whereas the congruent realisation by a finite verb seems to be more directly related to the concrete event. Grammatical metaphors are well suited for certain text types and target groups. In children's language development, however, they are mastered rather late (Halliday 1989: 95-96) and therefore should not be overused in children's books.

For the reasons mentioned above, NCs might be assumed to occur infrequently in Finnish children's fiction, both original and translated. There are some linguistic studies of originally Finnish children's books whose findings support this assumption (Heinonen 1985; Lappalainen 1982; Manner \& Mertaniemi-Ruopsa 1986; Turunen 1984), but to my knowledge, no similar analyses of translations have been made (apart from Puurtinen 1995). In Puurtinen (1995) a quantitative syntactic analysis of 80 children's books was carried out manually in order to compare the frequencies of the four most complex and/or most common types of NCs in Finnish originals and EnglishFinnish translations. The research material was categorised into three groups according to the time of publication: 10 translations and 10 originals dated from 1940-69, 20 translations and 20 originals from 1970-85, and 10 translations and 10 originals from 1986-93. The main focus was thus on the 1970-85 material; the additional earlier and later periods were expected to reveal potential changes in syntax. The analysis was based on an excerpt of 2000 words from the beginning of each book. The results showed, as expected, that NCs tend to be infrequently used in Finnish originals. All three translation samples, however, showed a significantly higher degree of nonfiniteness than the contemporary Finnish originals. This is an interesting finding in light of some recent hypotheses about the universals of translation. The higher degree of nonfiniteness of the translations is in fact contrary to the explicitation hypothesis (Baker 1993: 243, 1995: 235-236, 1996: 180-181), according to which translated texts would have a higher level of explicitness than original texts and specific source texts. Frequent use of NCs tends to decrease, not increase, explicitness, albeit only "locally" in a text. NCs also raise the lexical density of the translations. In Laviosa-Braithwaite's study (1996) and Laviosa's investigation (this volume), however, translated texts are found to have a lower lexical density than target language originals. Of course other linguistic features in Finnish translations of children's books may counteract this effect of NCs on lexical density and readability. 
A high frequency of NCs may be regarded as a feature of translationese in Finnish children's literature. The term translationese refers to features which distinguish translated texts from original target language texts; for example lexical items or syntactic structures which are not used in their normal target language functions or whose distribution is unusual (see also Toury 1995: 206-220). The term is used here in a neutral sense with no negative implications. Translationese, then, deviates from the language of original target language literature and thus violates the norms of target language literature.

It seems that English-Finnish translations of children's books fail to conform to one of the target syntactic norms, consequently their acceptability may be lower than that of original books. The findings may also indicate the existence of partly different syntactic norms for translated and original children's literature: translational norms may permit a greater degree of nonfiniteness. If this is the case, and the translations follow the syntactic norms of their own literary subsystem, they may be acceptable as translated texts. Nevertheless, acceptability does not necessarily entail acceptance by readers, who may either accept or reject a translation depending on their personal preferences, reading experience, etc. Translational norms correlate with the position of translated literature in a target literary system. Polysystem theory (Even-Zohar 1990) assumes that translated literature is usually in a peripheral position and consequently adheres to established norms and conventionalized models. Within children's literature, which as a whole tends to be peripheral, translations might be the most marginal and the most conventional, adhering to dominant target norms. However, bearing in mind the considerable proportion of translations in Finnish children's fiction, they may have acquired a more central role and might even be an innovatory force; it is not implausible that translators of children's books create, perhaps unintentionally, new norms which may gradually make their way into original Finnish children's literature as well. The results of the syntactic analysis support this assumption: Finnish originals from 1986-93 appear to be approaching the translations' higher level of nonfiniteness. This possible trend is an interesting object for further study.

The research outlined so far will be pursued further, using computational techniques to analyse larger samples of the latest Finnish children's literature of the 1990s, which will consist of whole books instead of short excerpts. My hypotheses, based on my previous findings, are first, that current translations have a significantly higher frequency of NCs than Finnish originals; and second, that the syntax of the originals continues to approach that of translations in terms of nonfiniteness. This syntactic difference might thus be eventually levelled out. The study will start as a synchronic one, but later the corpus will be enlarged to include books from earlier decades so as to provide an enlightening time perspective. English source texts will be used as one source of explanations for the use of NCs, which can often be traced back to a formally corresponding source text structure (see Puurtinen 1995: 74-83). Other explanations can be sought in the changing attitudes towards children, the role and functions of children's literature, as well as its stylistic or aesthetic requirements (for a discussion of these factors, see Puurtinen, forthcoming).

\section{IDEOLOGY}

Ideology can appear in children's fiction in the form of explicit statements of ethical or moral principles, but as children's literature becomes less conspicuously didactic in the Western countries, ideology is most often now realised as implicit assumptions and values underlying the writer's linguistic choices. Knowles and Malmkjær (1996: 
41-80), following Thompson (1990: 59-67), describe five modes of operation of ideology - legitimation, dissimulation, unification, fragmentation, and reification - and identify a number of micro-linguistic (involving single words and phrases) and macrolinguistic strategies (involving a clause or more) which can be used to realise them. In the following, I will concentrate on reification and three associated strategies, passivisation, nominalisation, and premodified participial attribute constructions (the last is my addition to Knowles and Malmkjær's list) because of their connection to readability issues discussed above. These forms should be relatively easily retrievable by computer. It must be emphasized that none of the linguistic forms discussed here are always indicators of ideology in a text, therefore the linguistic analysis of texts must be supported by a good knowledge of the values held by the surrounding culture.

Through reification "relations of domination which are in effect transitory, historical states are presented as though they were timeless, natural and permanent" (Knowles \& Malmkjær 1996: 59). This definition could be extended to include values, beliefs and customs considered self-evident and legitimate in a culture. One of the linguistic structures which support reification is passivisation. Passive sentences can be an effective neutralizing means of representing actions, processes and participants in such a way that causal relations and responsibility for actions become obscure, as participants can be deleted from the sentence. The object of the process, and not the agent or actor as in active sentences, usually occupies the first position in the clause. Thus passivisation makes it possible to thematise the object and even leave the agent responsible for the action completely unmentioned, as in example 4 below from C.S. Lewis's The Last Battle and its Finnish translation, where both the source and the target sentences include passive forms (in bold face).

Example 4

The woods are laid waste. The axe is loosed against us. We are being felled. Great trees are falling, falling, falling. (Lewis 1980: 21)

Metsä on autioksi tehty. Kirves on meitä vastaan nostettu. Meidät kaadetaan. Suuret puut kaatuvat, ne kaatuvat, ne kaatuvat. (Helakisa 1988: 18)

(word-for-word translation: The forest has been made desolate. The axe has been lifted against us. We are being felled. Great trees are falling, they are falling, they are falling.)

Tony Trew's well-known article (1979) about the newspaper reporting of the Salisbury riots describes how The Times used passivisation to shift the focus away from the police (who shot a number of Africans) to their victims. For instance, in the headline "Rioting Blacks Shot Dead by Police as ANC Leaders Meet," the victims are in focus and appear responsible for the event because they are classified as "rioting" people. In children's literature passivisation could have educational implications: instead of an explicit statement of the principle that girls should be passive and quiet, whereas boys should be active and courageous, female characters can be assigned inactive participant roles, making them appear passive entities affected by actions instead of being active achievers themselves. In Knowles and Malmkjær's example (1996: 79-80) from The Secret Garden by F. Hodgson Burnett (1992/1911), role assignment is shown to correlate with the increased activity of one of the main characters. At the beginning of the story, Mary Lennox is less active and less often in the role of actor, i.e. things happen or are done to her rather than by her, while towards the end she becomes more active and tends to occupy the actor role in sentences. It would be interesting to compare the Finnish translation with the source text to see how this development is realised in Finnish. Passive forms are not likely to be used very frequently in children's literature owing 
to their negative effect on readability, but their rarity makes them an even weightier and more meaningful linguistic device.

Like passivisation, nominalisation can also be used to obscure agency, responsibility and causality (see Fairclough 1990: 109-139) because it allows deletion of participants from the sentence. Nominalisation, which is a grammatical metaphor, transforms a process into a state or an entity, thereby presenting an activity as something static and unalterable. In example 3 above, both the source text and the first target text nominalisations, which in their present context (the fantasy story The Wizard of $O z$ ) carry no ideological implications, may in a different context (e.g. in a realistic story) be interpreted as a way of distancing the reader from the fact that living creatures have to eat to survive, and from the distressing situation of scarcity of food. Finnish premodified participial attribute constructions are similar to nominalisations in that they can also turn a process into a mere modifier (as in example 2 above). Moreover, they can be seen as a method of classification (cf. Fowler \& Kress 1979). For instance, in the following Finnish translation of a sentence in Rudyard Kipling's The Jungle Book (1987/1894), the verb nukkua ('to sleep') appears as a premodifier to those who sleep, thus classifying gipsies and woodcutters as a group of people who tend to, and perhaps always have to, sleep outside. The premodified construction seems to be a lexical unit, a natural, fixed entity. No such impression is created by the source text's postmodification.

Example 5

It was the noise that bewilders woodcutters and gipsies sleeping in the open, and makes them run sometimes into the very mouth of the tiger. (Kipling 1987/1894: 11)

Se ääni juuri eksyttää ulkosalla nukkuvat puunhakkaajat ja mustalaiset ja saa heidät joskus juoksemaan suoraan tiikerin kitaan. (Pennanen \& Jaskari 1965: 5)

(word-for-word translation: That very noise misleads outside-sleeping woodcutters and gipsies and makes them sometimes run direct into the tiger's mouth.)

Other ideological discrepancies between translations and source texts might be discovered through a thorough comparison of the use of particular linguistic structures other than those mentioned above.

\section{CONCLUSION}

The two research objectives discussed in this paper are interrelated in more than one way. In addition to the fact that some linguistic forms which carry ideological meaning may reduce readability in a children's book, ideology and readability are related at the extratextual, socio-cultural level. Whether high readability of children's literature is considered to be of primary importance or not in society is an ideological question in itself. When didactic and patronising attitudes towards children were dominant in Finland before the 1970s, children's literature was perhaps expected to be very simple linguistically in order for young readers to fully comprehend the books' content and moral. The recent trend towards more complex syntax may be a sign of greater confidence in children's linguistic abilities and a more tolerant, "nonchalant" attitude towards children's literature. On the other hand, previous didacticism might alternatively have found expression in the use of complex language in children's books as a means of teaching children nonfinite constructions and other difficult forms, which are learned slowly. My findings do not, however, support this latter view (Puurtinen 1995).

The future research outlined here will be mainly descriptive. The aim is to give an account of what translations are like linguistically and ideologically in comparison with 
their source texts and target language originals, while attempting to find explanations for translational solutions and for potential differences between translations and other target language texts. As Baker (1993: 246) has observed, corpus-based methodology is particularly suited to the discovery of certain translational norms because it enables the analysis of sufficiently large corpora and thus increases the reliability and generalisability of the findings. The descriptive and explanatory method will later be complemented by a critical approach to translational practices which seem to have undesirable consequences for the young target group.

\section{Notes}

1. The studies outlined here are part of a larger corpus-based research project launched at the Savonlinna School of Translation Studies. The parallel corpus will comprise both fiction and non-fiction English, German and Russian source texts and their Finnish translations. No comparable corpus will be created, but corpora of original Finnish texts compiled elsewhere will be used.

2. Readability is treated as a quality of texts although a text actually has no inherent degree of readability, because readability varies in accordance with the capabilities of readers and the features of reading situations. 3. Lexical density can be calculated by dividing the number of lexical items (or content words, as against grammatical items, or function words) by the total number of words in a text (Halliday 1989: 61-62; Karvonen 1991: 162).

\section{REFERENCES}

Children's literature

BAUM, L. Frank (1982/1900): The Wizard of Oz, New York, Galahad Books.

BAUM, L. Frank (1977): Ozin velho, Transl. Kersti Juva, Helsinki, Otava.

BAUM, L. Frank (1977): Oz-maan taikuri, Transl. Marja Helanen-Ahtola, Hämeenlinna, Karisto.

BURNETT, F. Hodgson (1992/1911): The Secret Garden, London, Sainsbury Walker.

KIPLING, Rudyard (1987/1894): The Jungle Book, New York, Penguin.

KIPLING, Rudyard (1965): Viidakkokirjat, Transl. Eila Pennanen and Juhani Jaskari, Porvoo, WSOY.

LEWIS, C. S. (1980/1956): The Last Battle, London, William Collins \& Sons.

LEWIS, C. S. (1988/1979): Narnian viimeinen taistelu, Transl. Kaarina Helakisa, Helsinki, Otava.

\section{Research literature}

BAKER, Mona (1993): "Corpus Linguistics and Translation Studies - Implications and Applications", Mona Baker, Gill Francis and Elena Tognini-Bonelli (Eds), Text and Technology. In Honour of John Sinclair, Philadelphia/Amsterdam, John Benjamins, pp. 233-250.

BAKER, Mona (1995): "Corpora in Translation Studies: An Overview and Some Suggestions for Future Research", Target, 7 (2), pp. 223-243.

BAKER, Mona (1996): "Corpus-based Translation Studies: The Challenges that Lie Ahead", Harold Somers (Ed.), Terminology, LSP and Translation: Studies in language engineering in honour of Juan C. Sager, Philadelphia/Amsterdam, John Benjamins, pp. 175-186.

CHESTERMAN, Andrew (1993): "From 'Is' to 'Ought': Laws, Norms and Strategies in Translation Studies", Target, 5 (1), pp. 1-20.

DELABASTITA, Dirk (1991): "A False Opposition in Translation Studies: Theoretical versus/and Historical Approaches", Target, 3 (2), pp. 137-152.

EVEN-ZOHAR, Itamar (1990): Polysystem Studies. Poetics Today, 11 (1), Tel Aviv, The Porter Institute for Poetics and Semiotics, Tel Aviv University.

FAIRCLOUGH, Norman (1990/1989): Language and Power, London/New York, Routledge.

FOWLER, Roger and Gunther KRESS (1979): "Critical Linguistics", Roger Fowler, Bob Hodge, Gunther Kress and Tony Trew (Eds), Language and Control, London/Boston/Henley, Routledge \& Kegan Paul, pp. 185-213.

HALLIDAY, M.A.K. (1978): Language as Social Semiotic. The Social Interpretation of Language and Meaning, London, Edward Arnold.

HALLIDAY, M.A.K. (1986/1985): An Introduction to Functional Grammar, London, Edward Arnold.

HALLIDAY, M.A.K. (1989/1985): Spoken and Written Language, Oxford, Oxford University Press.

HEINONEN, Päivi (1985): Lauseenvastikkeiden sekä modaali- ja agenttirakenteiden käytöstä lastenkirjallisuudessa, Unpublished pro gradu thesis, Jyväskylä, University of Jyväskylä. 
HERMANS, Theo (1991): "Translational Norms and Correct Translations", Kitty M. van Leuven-Zwart and Ton Naaijkens (Eds), Translation Studies: The State of the Art, Amsterdam/Atlanta, Rodopi, pp. 155169.

KARVONEN, Pirjo (1991): "Kieliopillinen metafora ja sen vaikutukset tekstissä", Tapani Lehtinen and Susanna Shore (Eds), Kieli, valta ja eriarvoisuus. Esitelmiä 18. Kielitieteen päiviltä, Helsinki, University of Helsinki, pp. 149-165.

KNOWLES, Murray and Kirsten MALMKJÆR (1996): Language and Control in Children's Literature, London/New York, Routledge.

LAPPALAINEN, Marita (1982): Syntaksin piirteitä 1900-luvun alun ja 1970-luvun lastenkirjallisuudessa. (Kvantitatiivinen ja vertaileva analyysi), Unpublished pro gradu thesis, Tampere, University of Tampere.

LAVIOSA-BRAITHWAITE, Sara (1996): The English Comparable Corpus (ECC): A Resource and a Methodology for the Empirical Study of Translation, Unpublished PhD thesis, Manchester, University of Manchester Institute of Science and Technology.

MANNER, Teija and Seija MERTANIEMI-RUOPSA (1986): 1980-luvun alun lasten kertomakirjallisuuden kerronnan kieli, Unpublished pro gradu thesis, Oulu, University of Oulu.

PURANEN, Ulla (1981): Luettavuus lastenkirjallisuuden ominaispiirteenä. Empiirinen tutkimus lasten- ja aikuiskirjallisuuden luettavuudesta kolmen luettavuuskriteerin pohjalta, Reports from the Faculty of Education 5/1981, Oulu, University of Oulu.

PUURTINEN, Tiina (1993): "Kieliopilliset metaforat lastenkirjojen suomennoksissa", Virittäjä, 4, pp. 546563.

PUURTINEN, Tiina (1994): "Dynamic Style as a Parameter of Acceptability in Translated Children's Books", Mary Snell-Hornby, Franz Pöchhacker and Klaus Kaindl (Eds), Translation Studies: An Interdiscipline, Amsterdam/Philadelphia, John Benjamins, pp. 83-90.

PUURTINEN, Tiina (1995): Linguistic Acceptability in Translated Children's Literature, Joensuu, University of Joensuu.

PUURTINEN, Tiina (forthcoming): "Syntactic Norms in Finnish Children's Literature", Target.

RAVELLI, L. J. (1988): "Grammatical Metaphor: An Initial Analysis", Erich H. Steiner and Robert Veltman (Eds), Pragmatics, Discourse and Text. Some Systematically-Inspired Approaches, London, Pinter, pp. 133-147.

SIMPSON, Paul (1993): Language, Ideology and Point of View, London/New York, Routledge.

SNELL-HORNBY, Mary (1988): Translation Studies. An Integrated Approach, Amsterdam/Philadelphia, John Benjamins.

STEPHENS, John (1992): Language and Ideology in Children's Fiction, London/New York, Longman.

THOMPSON, J. B. (1990): Ideology and Modern Culture: Critical and Social Theory in the Era of Mass Communication, Cambridge, Polity Press.

TOURY, Gideon (1980): In Search of a Theory of Translation, Tel Aviv, The Porter Institute for Poetics and Semiotics, Tel Aviv University.

TOURY, Gideon (1995): Descriptive Translation Studies and Beyond, Amsterdam/Philadelphia, John Benjamins.

TREW, Tony (1979): "Theory and Ideology at Work", Roger Fowler, Bob Hodge, Gunther Kress and Tony Trew (Eds), Language and Control, London/Boston/Henley, Routledge \& Kegan Paul, pp. 94-116.

TURUNEN, Seija (1984): Suomalaisten satujen lauserakenteista ja sanaluokkajakaumasta luettavuuden kannalta, Unpublished pro gradu thesis, Joensuu, University of Joensuu. 